\title{
1993 REOBSERVATIONS OF THE TETON LEVELING LINE FOR THE ASSESSMENT OF EARTHQUAKE HAZARDS
}

\author{
ARTHUR G. SYLVESTER • DEPARTMENT OF GEOLOGICAL SCIENCES \\ UNIVERSITY OF CALIFORNIA • SANTA BARBARA \\ ROBERT B. SMITH $\bullet$ DAVID MOREY \\ UNIVERSITY OF UTAH $\diamond$ SALT LAKE CITY
}

\section{$\downarrow \quad$ INTRODUCTION}

The Teton normal fault, Wyoming, is characterized by a $55-\mathrm{km}$ long fault scarps of postglacial age $(<14,000$ yrs.). These well developed late Quaternary scarps range in height from 3 to $52 \mathrm{~m}$ (Smith et al., 1993; Byrd et al., 1994) and have been the locus of several large, scarpforming earthquakes.

The Teton fault is located in a tectonically active area of the Intermountain Seismic Belt but occupies a notable gap in the seismicity and is considered a major earthquake hazard to the region. The Teton fault is, therefore, considered a location of future large earthquakes with accompanying strain accumulation that may be measured by accurate measurements of changes in ground height, which has been the objective of our 1993 and past Teton fault leveling surveys.

A 1st-class, 1st-order level line was established across the Teton fault in Grand Teton National Park in 1988 and has been observed in 1989, 1991, and 1993 to assess long-term deformation. This document is a progress report of the most recent re-observations of the level line conducted in August, 1993.

\section{PRECISION SURVEYING RESULTS}

Surveying methods--The Teton leveling line consists of 50 bench marks ( 44 of which were established in 1988 and the remaining 6 added in 1989) spanning a distance of $22.1 \mathrm{~km}$ (Figure 1). The line begins near Deadman Bar on the west edge of the Snake River, and extends west to the Teton range. The line runs to the south of Jenny Lake and then proceeds up Cascade Canyon and ends near the head of Cascade Canyon (Figure 1).

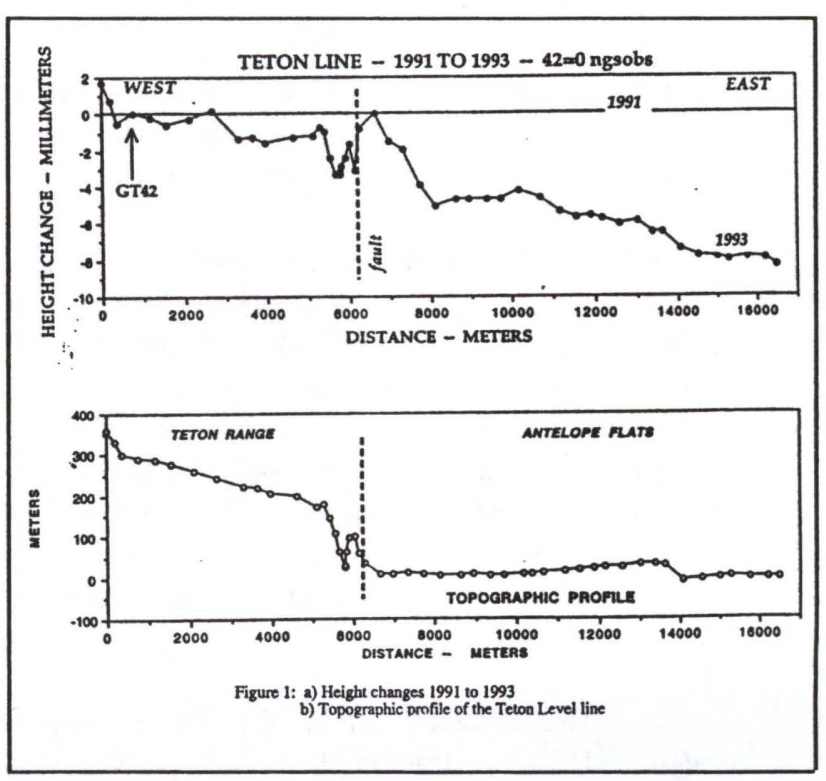


Bench marks GT01 through GT23 are Class B rod marks consisting of $2 \mathrm{~cm}$ diameter, 1-5 m-long steel rods. Each of these rods is encased by a $.5 \mathrm{~m}$ long, $20 \mathrm{~cm}$ diameter PVC pipe. The remaining bench marks consist of a $4 \mathrm{~cm}$ diameter stainless steel plug cemented into either bedrock or a large boulder. Each bench mark is equipped with a stainless steel cap so that the leveling rod makes a point contact with the mark. The bench marks are spaced abut 500 $\mathrm{m}$ apart, but some are as close as $240 \mathrm{~m}$ (GT33 and GT34).

The 1993 precise leveling observations were made during the last week of August and the first week of September. Two field crews consisting of two rod-persons, one recorder, and one instrument person surveyed different segments of the line. A Wild N3 and a Wild NAK2 instruments were used with Wild GPL-3 leveling rods, 4003A-B and 6477A$B$, respectively.

The survey was performed by a series of double-run loops that encompassed from two to six bench marks. The fore-run and back-run of a segment was shot by the same instrument person to minimize personal errors. Left-rod readings and right-rod readings were not permitted to deviate by more than $0.010 \mathrm{~cm}$, or the shot would be repeated. Preliminary closure errors were calculated in the field following the back-run of each segment. Closure errors and relative bench mark heights were calculated at the end of the day to check for errors in the field notes. The final data were submitted to the National Geodetic Survey (NGS) to be analyzed by their computer program REDUC4 to adjust the field observations for collimating and rod errors, differences in rod length, temperature, and refraction.

Precision of Survey--In order to obtain the quality of data necessary for this type of experiment very strict guidelines were followed. We sought to achieve closures considered "tectonic precision" which is equivalent to $1 \mathrm{~mm} \times \mathrm{L}^{1} / 2(\mathrm{~L}=$ length of the line $)$, as compared to "1st order precision" which is $2 \mathrm{~mm} \mathrm{x}$ $\mathrm{L}^{1} / 2$ and "second order precision" which is $5 \mathrm{~mm}$ $L^{1} / 2$. Thus, our goal was to obtain accuracy of one part per million which is equivalent to "tectonic 1st order precision".

The standard error for the survey was calculated using the methods of proportionality (Bouchard and Moffit, 1965):

$$
\sigma_{s}=\sqrt{\Sigma\left(\left(\frac{d_{1}}{2}\right)^{2}+\left(\frac{d_{2}}{2}\right)^{2}+\ldots+\left(\frac{d_{n}}{2}\right)^{2}\right.}
$$

where $d=$ the misclosure for an individual survey segment in $\mathrm{cm}$. The 1993 survey had 15 segments with "tectonic 1st order" precision and 7 segments with "1st order" precision. The observed total misclosure was less than $5 \mathrm{~mm}$.

\section{OBSERVATIONS}

Differencing the heights measured in the 1988 and 1993 Teton leveling surveys indicates that significant motion is associated with the Teton fault. Figure 1 shows that in the six year period, the hanging wall of the Teton fault dropped as much as $8.3 \mathrm{~mm}$ (Figure 1). The largest height change was centered near the Teton fault.

Preliminary Interpretation--The initial re-leveling surveys of the Teton level line between 1988-89 revealed reverse aseismic creep where the hanging wall rose compared to the footwall and was an unexpected motion for an active normal fault. The unusual deformation was interpreted to reflect shallow hydrologic flow south from Jackson Lake associated with the re-filling of Jackson Lake (Byrd, et al., 1994).

Following this unusual episode, the 1989-9193 surveys revealed down-to-the-west footwall subsidence which is the style expected with normalfault strain accumulation (Figure 2). The 1991-1993 deformation data for the Teton leveling line are currently being interpreted by Mr. David Morey, University of Utah, as the main part of his senior thesis.

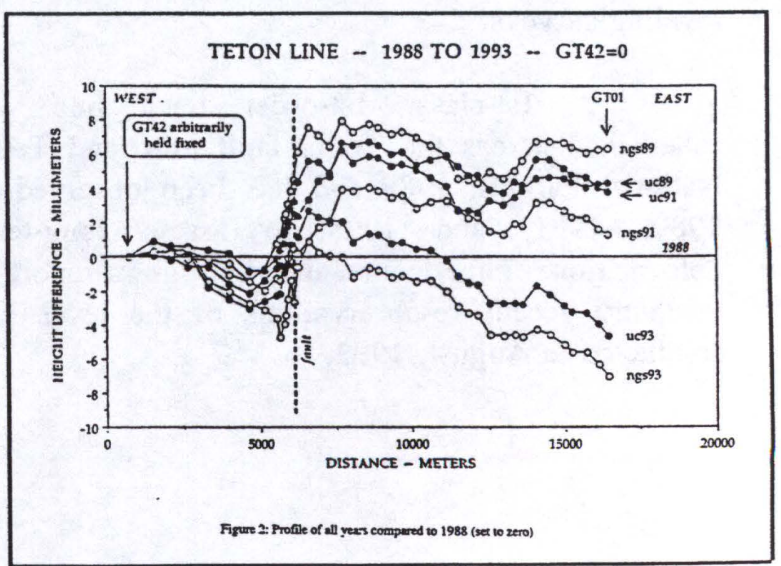


The overall trend of the 1989-1993 Teton leveling data reveal significant, down-to-the-east valley subsidence--the expected motion of tectonic loading on a normal fault preceding an earthquake. The deformation rate is $\sim 4 \mathrm{~mm} / \mathrm{yr}$ which is in general agreement with long-term loading rates discussed by Smith et al., (1993) and Byrd et al., (1994) but is significantly higher than surrounding normal faults of the Intermountain Seismic Belt.

\section{$\checkmark \quad$ ACKNOWLEDGEMENTS}

This research was supported by a grant from the National Science Foundation. The National Park Service and the University of Wyoming-National Park Service Research Center cooperated in the project.

\section{- Literature Cited}

Bouchard, H. and F. H. Moffit. 1995. Surveying, 5th edition, Inter. Textbook Co., Scranton, Penn., 754 pp.

Byrd, J. O. D., R. B. Smith and J. W. Geissman. 1994. The Teton Fault, Topographic Signature, Neotectonics and Mechanisms of Deformation. J. Geophys. Res. (in press).

Smith, R. B., J. O. D. Byrd and D. D. Susong. 1993. The Teton fault: Seismotectonics, Quaternary history and earthquake hazards. In A. W. Snoke, J. Steidtmann, and S. M Roberts, editors "Geology of Wyoming". Geological Survey of Wyoming Memoir No. 5, p. 628-667. 